\title{
Numerical Study of the Effect of Changing Tube Pitches on Heat and Flow Characteristics from Tube Bundles in Cross Flow

\author{
Petinrin M. O. ${ }^{{ }^{*}}$, Towoju O. A. ${ }^{2}$, Ajiboye S. A. ${ }^{1}$, Zebulun O. E. ${ }^{1}$ \\ ${ }^{1}$ University of Ibadan, Oduduwa Rd., Ibadan, Nigeria;
} \\ ${ }^{2}$ Adeleke University, P.M.B. 250, Ede-Osogbo Rd., Ede, Osun State, Nigeria
}

\author{
Article info: \\ Paper received: \\ The final version of the paper received: \\ Paper accepted online:
}

\author{
September 26, 2018 \\ April 4, 2019 \\ April 9, 2019
}

*Corresponding Author's Address: layopet01@yahoo.com

\begin{abstract}
Tube bundles are found in various heat transfer equipment for thermal energy transfer between fluids. However, the inter-spatial arrangement of the tubes of any tube bundle is a determining factor for its thermal and hydraulic performance. In this paper, the effect of varying the transverse and longitudinal pitches downstream staggered circular tube bundle on the heat transfer and flow characteristic was numerically analyzed. Seven variations of tube arrangements were studied by changing the tube pitches within a Reynolds number range of 7381 to 22214 . The analyses were carried out using the k- $\varepsilon$ equation model imposed with the realizability constraint and were solved with finite volume CFD code, COMSOL Multiphysics. The results obtained were found to be in good agreement with existing correlations. The tube bundles with decreasing pitches demonstrated better heat transfer performance while those with increasing pitches exhibited a lower friction factor. Thus, the best thermal-hydraulic performance was obtained from increasing pitch arrangements.
\end{abstract}

Keywords: cross flow, varying pitch, tube bundle, heat transfer, thermal-hydraulic performance.

\section{Introduction}

Tube bundle consists of multiple arrangements of tubes in series or parallel and is commonly found in heat exchangers $[1,2]$. In any typical arrangement, transfer of heat takes place between a fluid moving across/over the tubes and another at a different temperature passing through the tubes [2-4]. Applications of fluid flow and heat transfer across tube bundles in heat exchangers find application in many industrial processes, as is seen in air conditioner cooling, tubular heat exchangers, waste heat recovery and economizers, steam generators, hightemperature gas-cooled reactors and so on $[3,5,6]$.

There are many possible arrangements of tubes that can be obtained for effective heat transfer between fluids. The most common arrangements are the in-line and the staggered arrangements, and their spatial distributions are defined by transverse, longitudinal and diagonal pitches $[2,3,7]$. The difference in the recirculation and behaviour of flow becomes larger as the tube bundle compactness increases from a single tube [7]. This becomes more pronounced on the heat energy transfer and flow characteristics as spatial distributions and/or shapes of the tubes continue to change [8]. The flow resistance, which is in the form of pressure drop, over the tube bundles proportionately affects the fluid pumping power $[2,9]$.
Numerous studies have been conducted on the arrangements and geometries of tubes in efforts of improving the thermal performance of tube bundles without compromising the associated pressure drop, for effective designs of heat exchangers $[8,10]$. The results of the analytical study of heat energy transfer in cross flow for a tube bundle using the integral method by Khan et al. [3] showed that the more compact the tube banks the higher the heat transfer rates recorded and that the staggered arrangement had better heat transfer output then the inline arrangement. Tahseen et al. [11] studied experimentally, the laminar forced convection of air over in-line flat tube bundles. It was discovered that the average Nusselt number increased with the incremental changes in the heat flux when the Reynolds number increased from 527 to 880 . Mohanty et al. carried a study on the inline and staggered arrangement of mixed tubes of circular and elliptical forms and observed that the heat transfer decreased while pressure drop increased tube while form changed from pure circular to mixed form arrangement [12].

Buyruk [8] investigated the flow and heat transfer around cylinders in cross-flow with blockages. It was discovered that the local Nusselt number and pressure coefficient distributions were significantly affected by blockage ratios. They reported that the lower aspect-ratio 
tubes had more effect on flow and thermal characteristics of tube bundles as the angle of attack changes than the higher aspect-ratio tubes. Jeong et al. [4] carried out both experimental and numerical studies of heat transfer performance over a mini-channel tube bundle. With the use of two, the log means temperature difference (LMTD) and surface temperature methods to evaluate the transfer coefficients of the convective heat of the tube bundles. It was discovered that the experimental and numerical studies were in close agreement and the average Nusselt number based on the LMTD method was $22.6 \%$ less than that of the surface temperature method.

Barcellos [13] investigated the effect of angle of inclination of a tube bundle of circular tubes on heat transfer and pressure drop in an experiment. The heat transfer rate and pressure drop recorded increased with inclination angle and were at the maximum at angle $45^{\circ}$ to the normal. The higher pressure drop was attributed to vortex shedding and secondary flow due to recirculation. A similar study on the effect of angles of attack was performed experimentally by Toolthaisong and Kasayapanand [14] on flat tubes with different aspect ratios in staggered arrangement.

Numerical studies performed by Lee et al. [15] on the impact of uneven longitudinal pitch on the heat transfer performance of in-line tube bundle in cross flow showed that the overall heat transfer was improved by increasing the longitudinal pitch for uniformly distributed tubes. Their correlations were in close agreement with experimental data from the literature. Also, in the computational study of wall-bounded tube bundles in cross flow by $\mathrm{Li}$ et al. [1], the heat transfer coefficient in the near wall tubes and turbulence intensity of the near wall flow passages were lower than those in the middle of the bundle.

Several studies have also been carried out on tube bundles with extended surfaces. Hofmann et al. [16] experimentally investigated forced convection over tube bundles with different serrated and solid fin geometries. The Nusselt number and the pressure drop coefficient correlations compared well with literature. Similar research works on extended surfaces, the serrated finnedtube bundles were carried out by Hofmann et al. [17,18]. Insights into the heat transfer and fluid dynamic performance of tube bundles with non-circular geometries other than flat tubes are on the rise because of the satisfactory performance of the tubes [19]. Some of the research works on non-circular tubes includes: the numerical study of Horvat et al. [20] on cylindrical, ellipsoidal and wingshaped tubes in staggered arrangement; the experimental studies of Mangrulkar et al. [10], Nouri-Borujerdi and Lavasani [21], and Lavasani et al. [22] on cam-shaped tube bundles in cross flow; and the work of Du et al. [23] on finned oval-tube cross-flow heat exchanger.

Thus, the findings from the previous studies have shown that arrangements, geometrical configurations, and surface treatments have a pronounced effect on the flow and thermal characteristics of tube bundles in cross flow. However, from these studies, there has been little or no emphasis on changes in transverse and longitudinal pitches downstream of tube bundles. In the present study, the effect of the downstream variation in the transverse and longitudinal pitches on the heat transfer and flow characteristic across the staggered circular tube bundle will be numerically investigated.

\section{Research Methodology}

\subsection{Geometry of the tube bundles}

Computational studies were conducted on tube bundles with varying pitches in a staggered arrangement to determine the temperature change and pressure drop of the air flowing across it. The arrangements of the tubes were made in seven forms:

- tube bundle with fixed pitch (TBFP), standard;

- tube bundle with decreasing longitudinal pitch (TBDLP);

- tube bundle with decreasing transverse pitch (TBDTP);

- tube bundle with decreasing pitches, both transverse and longitudinal (TBDP);

- tube bundle with increasing longitudinal pitch (TBILP);

- tube bundle with increasing transverse pitch (TBITP);

- tube bundle with increasing pitches, both transverse and longitudinal (TBIP).

Three extreme cases of the tube arrangements are as depicted in Figure 1. The TBFP is a standard tube arrangement having transverse pitch ratio $p=1.50$. Therefore, its transverse pitch, $p_{T}$ was determined as

$$
p_{T}=1.5 d_{0}
$$

To form an equilateral triangular tube layout, the longitudinal pitch was calculated as

$$
p_{L}=\frac{\sqrt{3}}{2} p_{T} \text {. }
$$

The transverse pitches for other tube arrangements were determined from the products of the outer diameter, $d_{0}$ and pitch ratios of $1.60,1.55,1.50,1.45$ and 1.40, which gives an average of 1.50 . Their longitudinal pitches $\left(p_{L 1}, p_{L 2}, p_{L 3}\right.$, and $\left.p_{L 4}\right)$ were chosen with an arbitrary decrement or increment of $0.69 \mathrm{~mm}$. However, for all the three arrangements, the distances between their first and last columns were the same. The geometrical parameters of the tube bundles are as depicted in Table 1. 


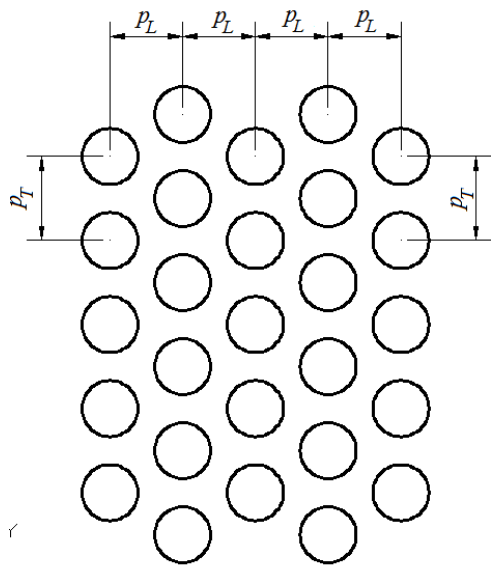

a

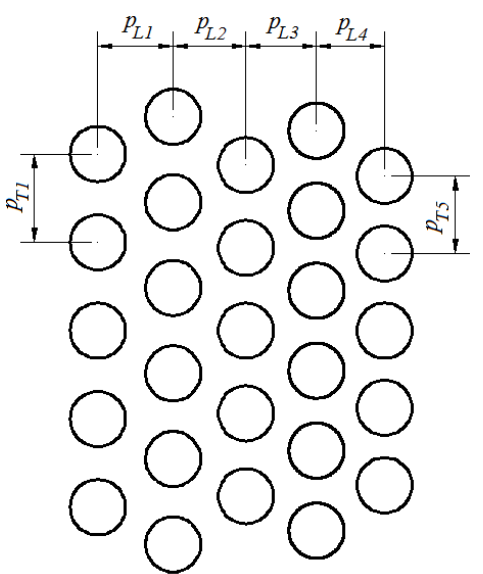

$\mathrm{b}$

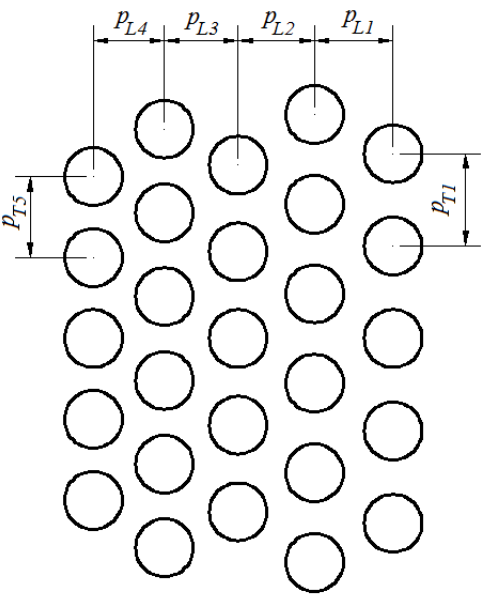

c

Figure 1 - The tube layout arrangements of TBFP, TBDP, and TBIP

Table 1 - The geometrical parameters of the tube bundles

\begin{tabular}{|c|c|c|}
\hline \multicolumn{2}{|c|}{ Parameter } & Value \\
\hline \multicolumn{2}{|c|}{ Tube outside diameter $d_{0}, \mathrm{~mm}$} & 15.88 \\
\hline \multicolumn{2}{|l|}{ Tube thickness $t, \mathrm{~mm}$} & 1.62 \\
\hline \multicolumn{2}{|l|}{ Tube length $L, \mathrm{~mm}$} & 150 \\
\hline \multicolumn{2}{|l|}{ Tubes number $n$} & 27 \\
\hline \multicolumn{2}{|l|}{ Tubes number of rows } & 11 \\
\hline \multicolumn{2}{|l|}{ Tubes number of columns } & 5 \\
\hline \multirow[t]{3}{*}{ Transverse pitch, mm } & TBFP, TBDLP, TBILP & 23.81 \\
\hline & TBDP, TBDTP & $25.40,24.61,23.81,23.02,22.23$ \\
\hline & TBITP, TBIP & $22.23,23.02,23.81,24.61,25.40$ \\
\hline \multirow[t]{3}{*}{ Longitudinal pitch, mm } & TBFP, TBDTP, TBITP & 20.62 \\
\hline & TBDLP, TBDP & $21.65,20.97,20.28,19.59$ \\
\hline & TBILP, TBIP & $19.59,20.28,20.97,21.65$ \\
\hline
\end{tabular}

\subsection{Numerical simulation}

In the computational model, the thermo-physical properties of the fluid and tube materials were assumed to be constant. Also, the cross flow over the tube bundles was considered to be steady and incompressible, because the highest Mach number of flow obtained from preliminary calculation was less than the threshold of 0.3 [10]. Thus, the flow over the tube bundles follows as:

The continuity equation:

$$
\frac{\partial U_{j}}{\partial x_{j}}=0
$$

Reynolds averaged Navier-Stokes (RANS) equations:

$$
\begin{aligned}
& \rho \frac{\partial\left(U_{j} U_{i}\right)}{\partial x_{j}}=-\frac{\partial P}{\partial x_{i}}+ \\
& \frac{\partial}{\partial x_{j}}\left[\mu\left(\frac{\partial U_{i}}{\partial x_{j}}+\frac{\partial U_{j}}{\partial x_{i}}\right)-\rho \overline{u_{i}^{\prime} u_{j}^{\prime}}\right]
\end{aligned}
$$

Energy equation:

$$
\rho c_{p} \frac{\partial\left(U_{j} T\right)}{\partial x_{j}}=\frac{\partial}{\partial x_{j}}\left(\left(\eta+\eta_{T}\right) \frac{\partial T}{\partial x_{j}}\right)
$$

where $x_{i}(i=1,2)$ is the coordinates, $U_{i}$ represents the velocity vector, $p$ is the pressure, $T$ stands for temperature, $\rho$ is the density, $\mu$ is the dynamic viscosity, $\mu_{T}$ is the turbulent eddy viscosity, $c_{p}$ represents the specific heat capacity, $\eta$ is the thermal conductivity, $\eta_{T}$ stands for turbulent thermal conductivity and $\rho \overline{u_{i}^{\prime} u_{j}^{\prime}}$ is the Reynolds stress tensor.

The turbulent eddy viscosity as obtained from [24-28] to impose the realizability constraint is

$$
\mu_{T}=\rho \times \max \left(\mu_{\min }, l_{m} \sqrt{k}\right)
$$

and

$$
l_{m}=\min \left(C_{\mu} \frac{k^{3 / 2}}{\varepsilon}, l_{\max }, \frac{\sqrt{k}}{3} \frac{1}{\max \lambda_{e}}\right)
$$


Here $\mu_{\min }$ is a fraction or a value of the laminar viscosity, $\mu$ and $l_{m}$ is the limited mixing length. $l_{\max }$ is the maximum permissible mixing length and $\lambda_{e}(e=1,2,3)$ are strain rate tensor eigenvalues.

Also, the turbulent thermal conductivity is defined as

$$
\eta_{T}=\frac{\mu_{T} c_{p}}{\operatorname{Pr}_{T}}
$$

The Boussinesq closure approximation to the Reynolds stress tensor in equation (4) is given as [29-31]

$$
\begin{aligned}
& -\rho \overline{u_{i}^{\prime} u_{j}^{\prime}}=\mu_{T}\left(\frac{\partial U_{i}}{\partial x_{j}}+\frac{\partial U_{j}}{\partial x_{i}}\right)- \\
& \frac{2}{3} \rho k \delta_{i j}
\end{aligned}
$$

Thus, in resolving the RANS equations, the $k-\varepsilon$ turbulent model was employed with the following additional transport equations:

Turbulent kinetic energy:

$$
\begin{aligned}
& \rho \frac{\partial\left(U_{j} k\right)}{\partial x_{j}}=\frac{\partial}{\partial x_{j}}\left[\left(\mu+\frac{\mu_{T}}{\sigma_{k}}\right) \frac{\partial k}{\partial x_{j}}\right]+ \\
& {\left[\mu_{T}\left(\frac{\partial U_{i}}{\partial x_{j}}+\frac{\partial U_{j}}{\partial x_{i}}\right)-\frac{2}{3} \rho k \delta_{i j}\right] \frac{\partial U_{i}}{\partial x_{j}}-}
\end{aligned}
$$

$\rho \varepsilon$

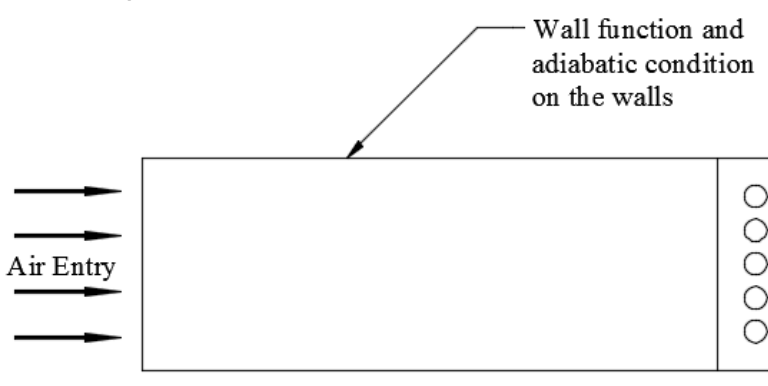

Figure 2 - The detail description of the boundary conditions
Turbulent dissipation energy:

$$
\begin{aligned}
& \rho \frac{\partial\left(U_{j} \varepsilon\right)}{\partial x_{j}}=\frac{\partial}{\partial x_{j}}\left[\left(\mu+\frac{\mu_{T}}{\sigma_{\varepsilon}}\right) \frac{\partial \varepsilon}{\partial x_{j}}\right]+ \\
& C_{\varepsilon 1} \frac{\varepsilon}{k}\left[\mu_{T}\left(\frac{\partial U_{i}}{\partial x_{j}}+\frac{\partial U_{j}}{\partial x_{i}}\right)-\frac{2}{3} \rho k \delta_{i j}\right] \frac{\partial U_{i}}{\partial x_{j}}- \\
& C_{\varepsilon 2} \rho \frac{\varepsilon^{2}}{k}
\end{aligned}
$$

The closure constants for the transport equations are given as $C_{\varepsilon 1}=1.44, C_{\varepsilon 2}=1.92, C_{\varphi}=0.09, \sigma_{k}=1.0$, and $\sigma_{\varepsilon}=1.3$

\subsection{Initial and boundary conditions with the mesh structure}

The initial velocity, pressure, and temperature of the fluid were set at zero, atmospheric pressure and $298 \mathrm{~K}$, respectively. Velocity-inlet and temperature-inlet conditions were imposed at the inlet of the computational domain. The velocity was varied from 5 to $15 \mathrm{~m} / \mathrm{s}$ at the constant inlet temperature of $301.15 \mathrm{~K}$. The temperature of the tube walls was fixed at $332.15 \mathrm{~K}$. Outlet boundary condition was set at the exit with zero gauge pressure and zero gradients for other primitive variables. Wall functions were applied to the walls of the tubes and the channels. The detail description of the boundary conditions as being applied to the computational domain is shown in Figure 2.

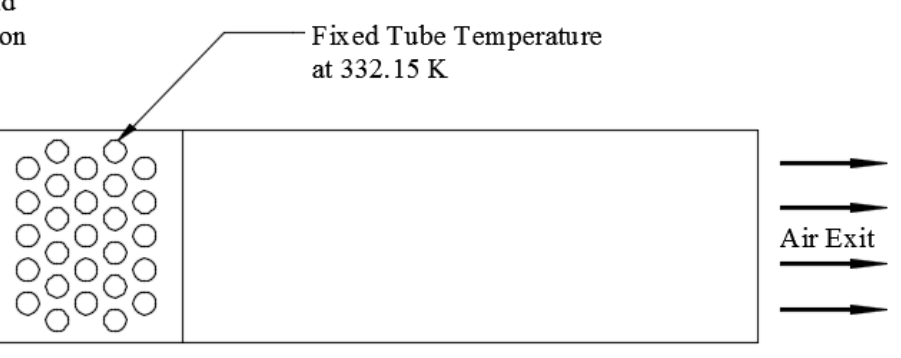

The finite element based COMSOL Multiphysics CFD code was used to solve the governing equations on the computational domain. The mesh structure of the domain contains both triangular and rectangular elements as shown in Figure 3. In order to resolve the sharp temperature and velocity gradients in the region of the near-wall, the mesh in this region was refined well with rectangular elements. Five different mesh grids were generated to carry out the numerical independence of the grids. They are 18 150, 26732,44 464, 62 714, 98100 and 125522 finite elements. The last three mesh elements had small relative differences of 0.8 and $4 \%$ for the coefficient of heat transfer and overall pressure drop, respectively. Therefore, 98100 mesh grid was selected for this study to save computational time. The dimensionless sublayerscaled wall distance at which the logarithmic layer intersects the viscous sublayer was found to be at approximately 11.06 .

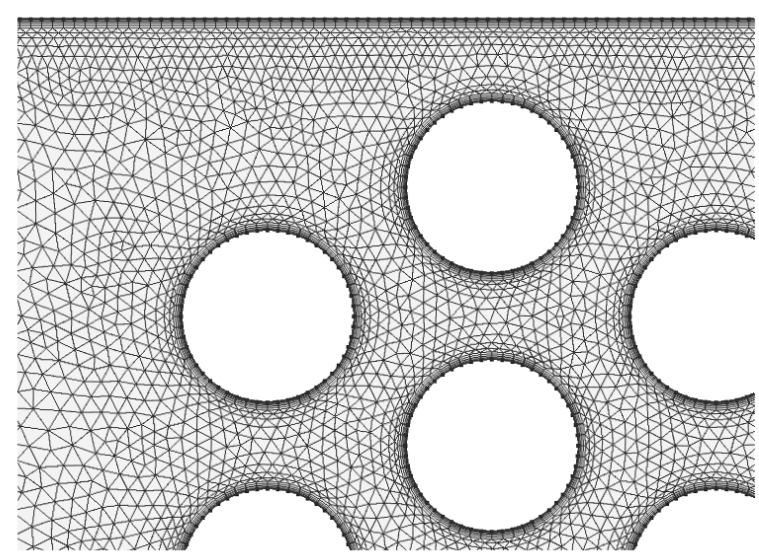

Figure 3 - The finite element grid 


\subsection{Data reduction}

It was assumed that the outer wall temperature, $T_{w}$ of each tube was the same as the bulk temperature of the hot water. This is the average of the water temperatures in the jackets. Also, the heat loss to the surroundings was assumed to be negligible. Thus, the heat transfer rate between the walls of the tube bundles and the air flow is given by $[19,32]$

$$
Q=h A \Delta T_{L M}
$$

The log mean temperature difference is

$$
\Delta T_{L M}=\frac{\left(T_{w}-T_{\text {in }}\right)-\left(T_{w}-T_{\text {out }}\right)}{\ln \frac{\left(T_{w}-T_{\text {in }}\right)}{\left(T_{w}-T_{\text {out }}\right)}}
$$

The tubes outer surface area was calculated from

$$
A=\pi d_{o} \operatorname{Ln}
$$

Thus, in order to determine the coefficient of heat transfer, the rate of heat transfer from equation (12) was obtained from the heat that accompanied the temperature difference within the air stream as

$$
Q=\dot{m} c_{p}\left(T_{\text {out }}-T_{\text {in }}\right)
$$

Therefore, the Nusselt number was calculated as

$$
N u=\frac{h d_{o}}{k}
$$

The air flow Reynolds number through the tube bundle as obtained from Bergman et al. [9] was estimated as

$$
\operatorname{Re}=\frac{\rho v_{\max } d_{o}}{\mu}
$$

where $v_{\max }$ is a mean velocity of the most narrow section of the tubes. Using TBFP arrangement, it is determined as follows

$$
v_{\max }=\frac{p_{T}}{2\left(p_{D}-d_{o}\right)} v
$$

The friction factor from the pressure drop across the tube bundle was calculated from Holman [33] as

$$
f=\frac{\Delta p}{2 \rho v_{\max }^{2} N}\left(\frac{\mu}{\mu_{w}}\right)^{0.14}
$$

where $N$ is the main resistance of the flow.
Thermal-hydraulic performance factor of the tube bundles is defined as [22]

$$
\eta=\frac{(N u / f)_{T B F P}}{(N u / f)}
$$

\subsection{Model validation}

The present predictions from the study were compared with the results of correlations available in the literature (Cengel, Incropera7). The comparisons as obtained for the tube bundle with fixed pitch are presented in Figure 4 for the Nusselt number and friction factor. It is clearly shown that the predicted values were in good agreement with the existing experimental and analytical correlations. However, the variations of Nusselt number in the present study from Zukauskas [34], Aiba [35] and Khan [3] correlations were found to be $28.5,12.6$ and $8.1 \%$, respectively. The predicted friction factor has a variation of 18.0 from Jakob's correlation [33]. The observed discrepancy might be as a result of making the few tubes wallbounded and also differences caused by the uncertainties of the numerical simulations and the correlations.

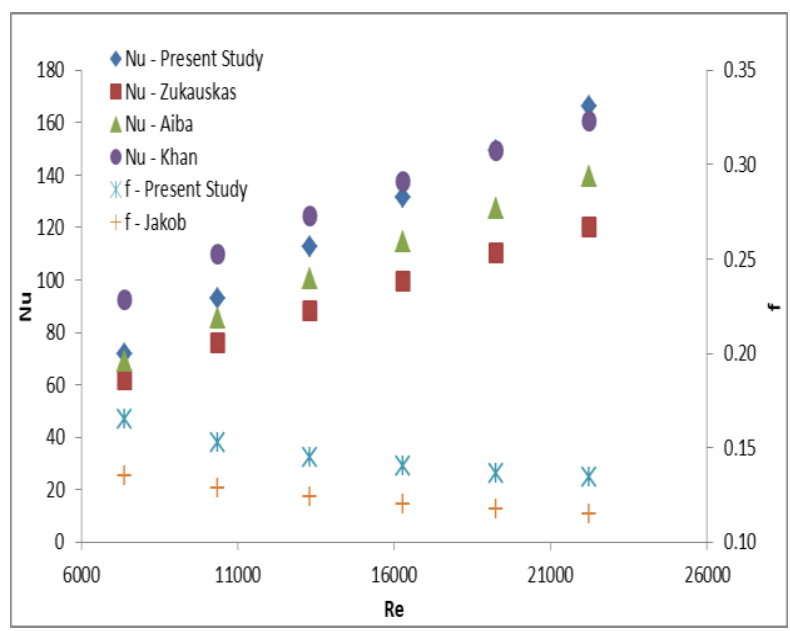

Figure 4 -Comparison of results with existing correlations

\section{Results and Discussion}

The streamlines and distributions of fluid velocity across the tube bundles for TBFP, TBDP, and TBIP at Reynolds numbers of 7381 and 22214 are as indicated in Figure 5. These arrangements were selected as extreme cases to explain the flow distributions. From the figure, the maximum flow velocity can be found within the regions in-between the tubes, and the tubes and walls. The wakes developed behind each tube are similar for all the tube arrangements and these regions are characterized with very low velocity. Wakes behind the first four columns are smaller as compared with the last column, and this could be attributed to the delay in onset of flow separation and change in flow structure caused by the tube columns behind the first four columns. However, in the wake region, the heat transfer rate would be at its lowest. 


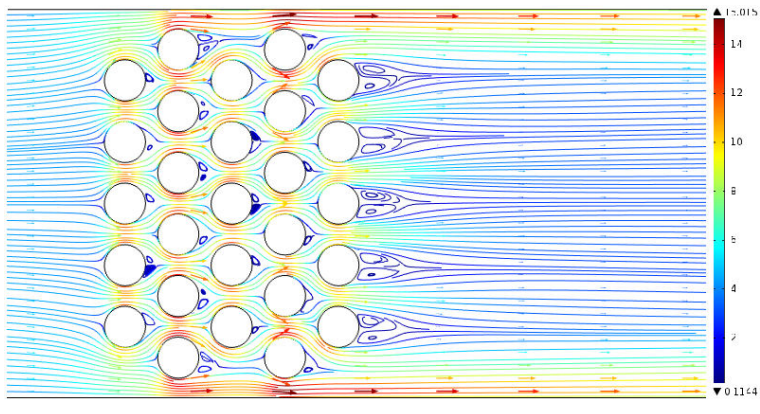

a
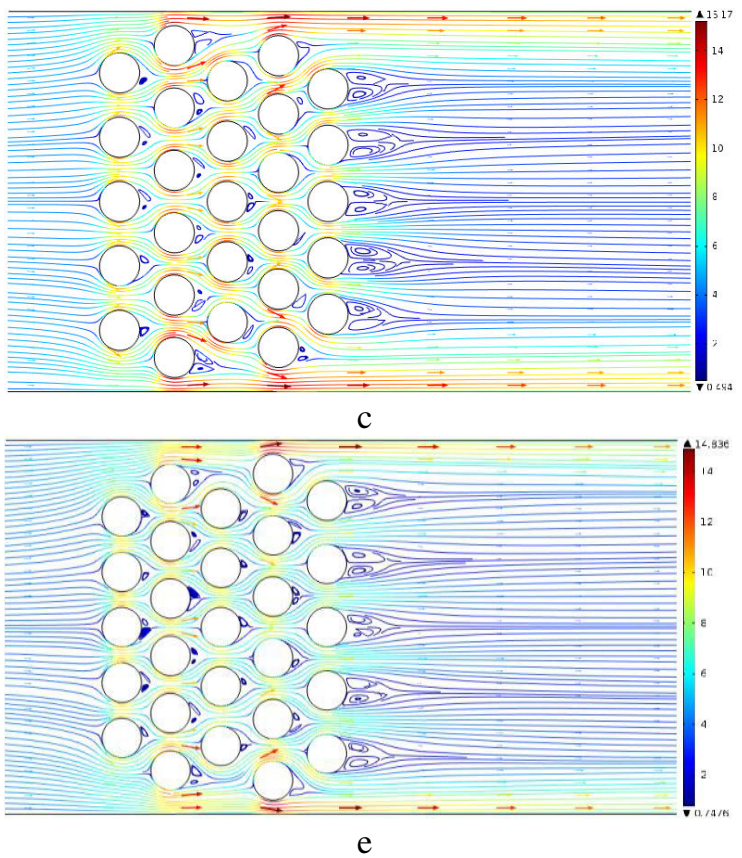

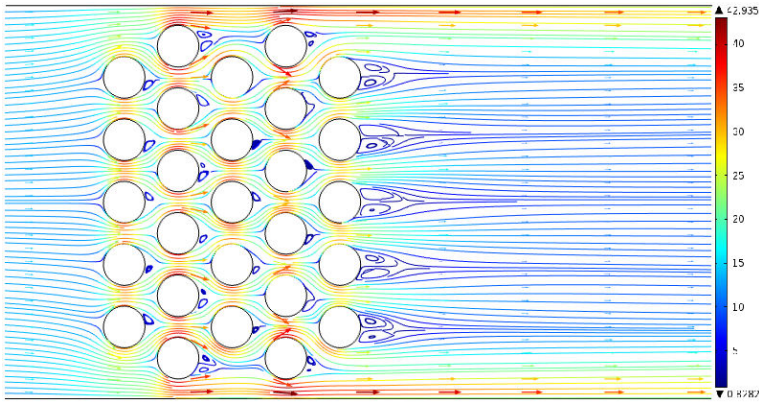

b
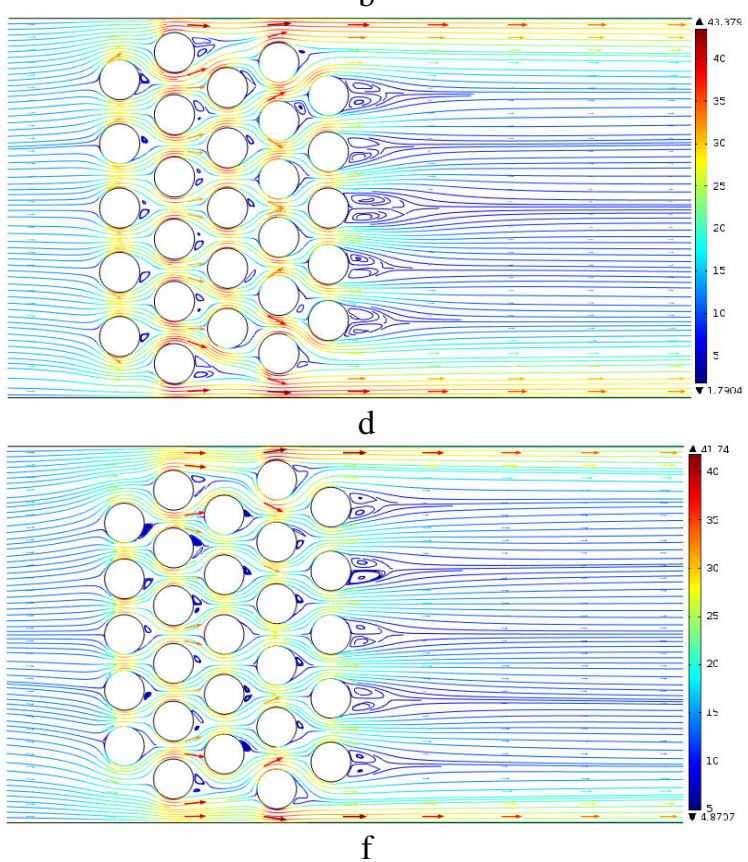

Figure 5 - Streamlines and distributions of fluid velocity across the tube bundles: $\mathrm{a}-\mathrm{TBFP}$ at $\operatorname{Re}=7381 ; \mathrm{b}-\mathrm{TBFP}$ at $\operatorname{Re}=22$ 214; $\mathrm{c}-\mathrm{TBDP}$ at $\operatorname{Re}=7381$;

$\mathrm{d}-\mathrm{TBDP}$ at $\operatorname{Re}=22214 ; \mathrm{e}-\mathrm{TBIP}$ at $\operatorname{Re}=7381 ; \mathrm{f}-\mathrm{TBIP}$ at $\mathrm{Re}=22214$

The distribution patterns of the turbulent kinetic energy within the tube bundles for TBFP, TBDP, and TBIP at Reynolds numbers of 7381 and 22214 are as shown in Figure 6 . The maximum energy averagely increases from 16 to $140 \mathrm{~m}^{2} / \mathrm{s}^{2}$ as the Reynolds number increases between the two bounds. There is a sharp increase in turbulent energy as the tube column increases; this is partly due to the effect of the preceding columns on the tubes downstream. The flow turbulence intensity, which is seen to be more pronounced at the leading edges and the spaces in-between tubes will eventually cause a higher heat transfer rate at these regions. However, the low-intensity turbulence found in the trailing edges of the tubes may be attributed to the characteristically low velocity wakes in the regions, thereby reducing thermal energy transfer [10]. As seen from the figure, the TBDP and TBIP produced higher and lower turbulent kinetic energy, respec- tively. This is an indication that the downstream decrease in tube pitch creates more interaction between the fluid and the tube surfaces.

Figure 7 shows the comparison of the Nusselt number for all the tube arrangements over a range of Reynolds number. It can be observed for each of the tube arrangement that the Nusselt number increases as the Reynolds number increases. However, there were very small variations in the Nusselt number; the value for TBFP, which is tube bundle with fixed pitch, is averagely greater with $0.7,0.9,0.1$, and $0.9 \%$ than TBDLP, TBILP, TBITP, and TBIP, respectively. However, its Nusselt number is less with 1.0 and $1.6 \%$ than TBDTP and TBDP, respectively. Except for TBDLP, there was an increase in the Nusselt number as the pitches decrease downstream, this is partly due to an increase in turbulent interaction within the fluid, and fluid with tube surfaces. 


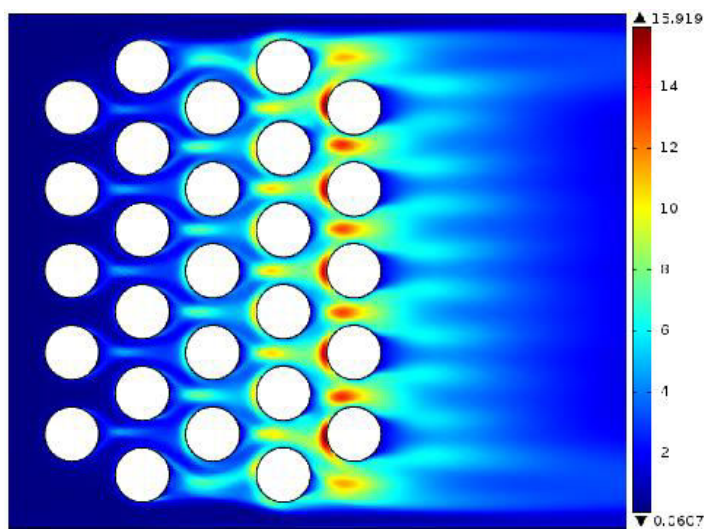

a

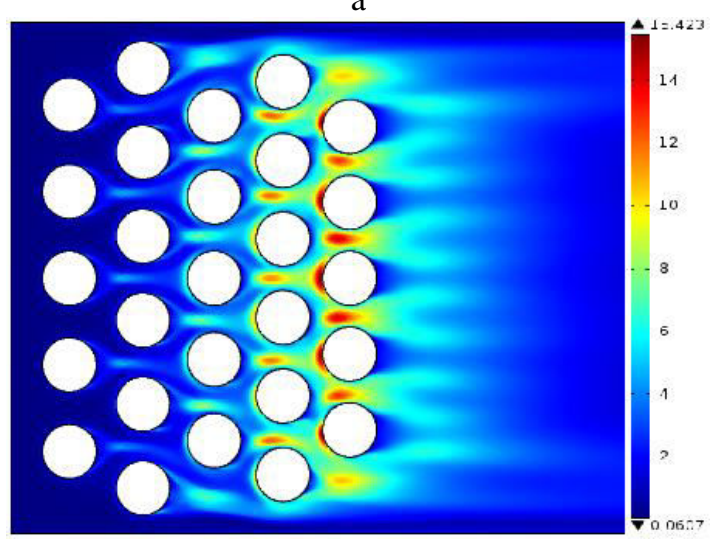

c

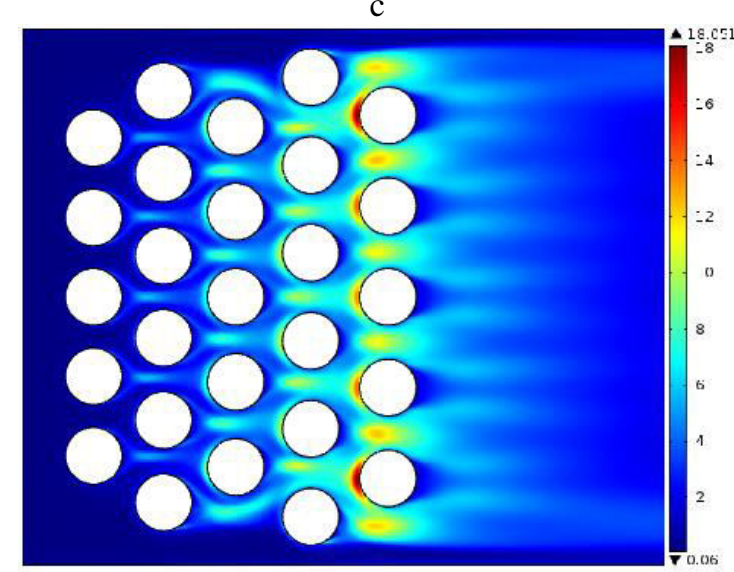

e

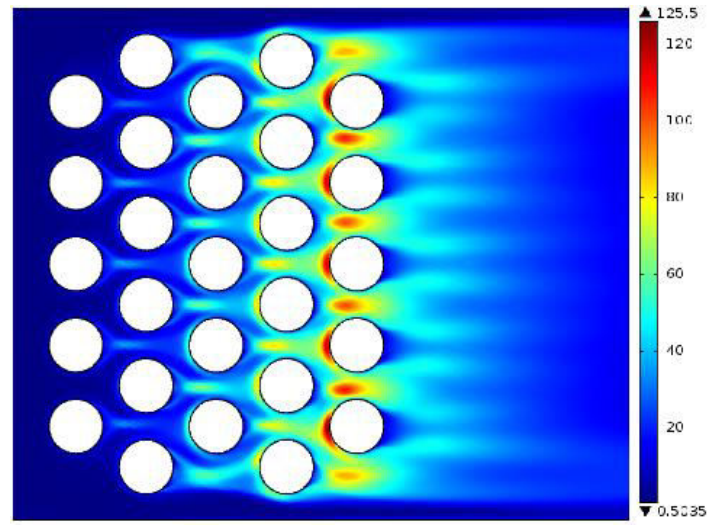

b

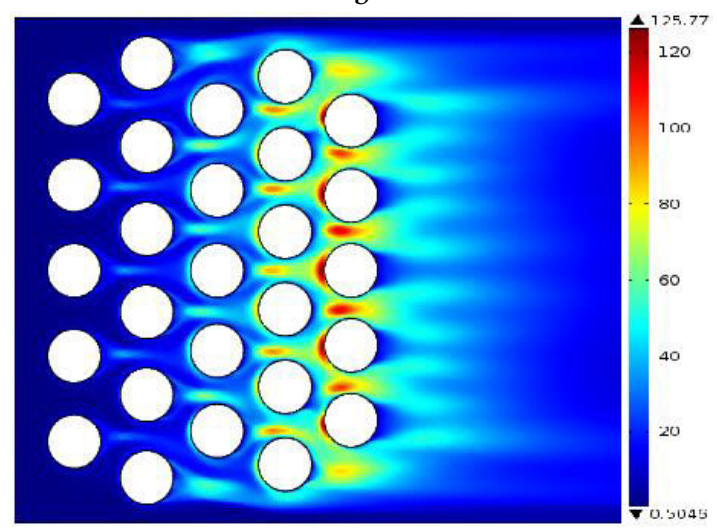

d

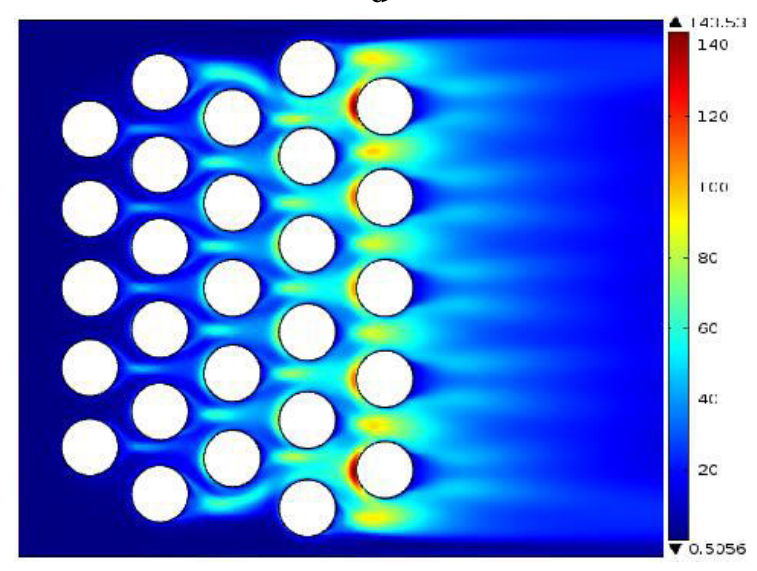

f

Figure 6 - Turbulent kinetic energy distributions within the tube bundles: $\mathrm{a}-\mathrm{TBFP}$ at $\operatorname{Re}=7381 ; \mathrm{b}-\mathrm{TBFP}$ at $\operatorname{Re}=22214 ; \mathrm{c}-$ TBDP at $\operatorname{Re}=7381$; $\mathrm{d}-\mathrm{TBDP}$ at $\operatorname{Re}=22$ 214; e - TBIP at $\operatorname{Re}=7381 ; \mathrm{f}-\mathrm{TBIP}$ at $\operatorname{Re}=22214$

The friction factor for all the tube arrangements as against the Reynolds number is as presented in Figure 8. It is obvious that the friction factor reduces with increasing Reynolds number for all arrangements. The friction factor is lowered for dominantly increasing the kinetic energy of the fluid with increasing Reynolds number. From the figure, the friction factor of TBFP (standard) is about 1.0, 1.1, and $1.4 \%$ less than TBDLP, TBDTP and TBDP, respectively. While the friction factor of the TBFP is greater than TBILP, TBITP and TBIP with 1.1, 0.9 , and $1.2 \%$, in that order. The trend indicates that the pitches of the tube columns downstream have a more pronounced effect on friction factor as compared with the pitches upstream.

The plot of the thermal-hydraulic performance factor for all tube arrangements as against the Reynolds number is as shown in Figure 9. There is no significant variation in the efficiency with the range of Reynolds numbers, except for TBDLP which decreases over the range. It can be seen that the increasing pitch arrangements display better thermal-hydraulic performance while the performance of the decreasing pitch arrangements is lower than the tube arrangement with a fixed pitch. 


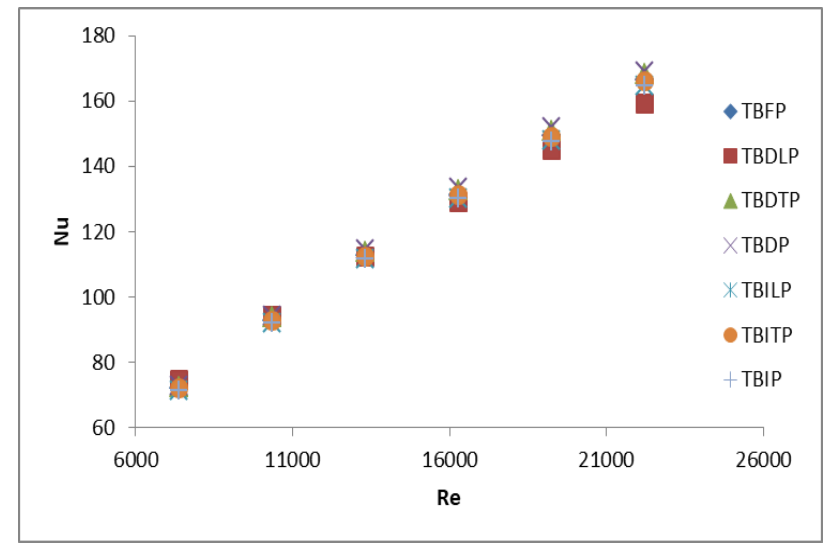

Figure 7 - The tube bundles average Nusselt number against the Reynolds number

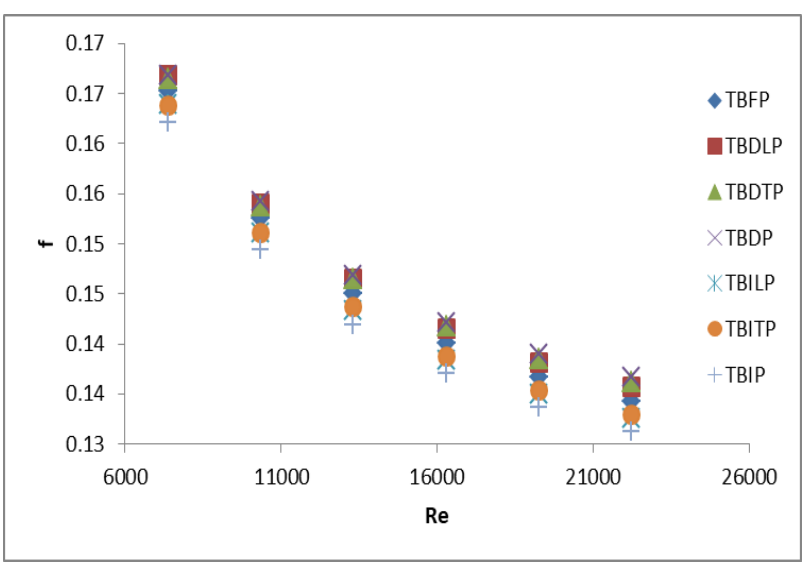

Figure 8 - The friction factor across the tube bundles against the Reynolds number

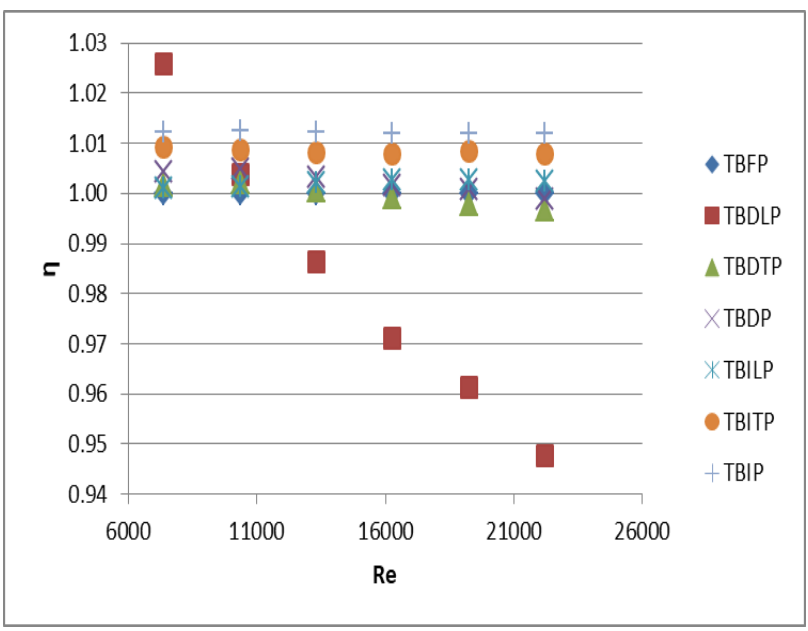

Figure 9 - The thermal-hydraulic performance factor of the tube bundles against the Reynolds number

\section{Conclusion}

The effects of varying downstream, the transverse and longitudinal pitches on the thermal-hydraulic performance of staggered tube arrangements were studied numerically. Seven tube arrangements were considered within a Reynolds number range. The results obtained indicated that the changes in the tube pitches affected the performance of the cross-flow heat transfer over the tube bundles. The tube bundles with decreasing pitches had the highest heat transfer performance. The lowest friction factor was obtained from the tube bundles with increasing pitches, which also gave the best thermal-hydraulic performance.

\section{Nomenclature}

\subsection{Abbreviations and symbols}

$d \quad$ Tube diameter;

$p_{T} \quad$ Transverse pitch, m;

$p_{L} \quad$ Longitudinal pitch, $\mathrm{m}$;

$p_{D} \quad$ Diagonal pitch, m;

$U \quad$ Velocity component, $\mathrm{m} / \mathrm{s}$;

$P \quad$ Pressure, $\mathrm{Pa}$;

$T \quad$ Temperature, $\mathrm{K}$;

$x \quad$ Cartesian coordinate, $\mathrm{m}$;

$k \quad$ Turbulence kinetic energy, $\mathrm{m}^{2} / \mathrm{s}^{2}$;

$l_{\min } \quad$ Size of the minimum permissible eddies, $\mathrm{m}$;

$l_{\max }$ Maximum permissible mixing length, $\mathrm{m}$;

$l_{m} \quad$ Limited mixing length, $\mathrm{m}$;

Re Reynolds number;

$\operatorname{Pr}_{T} \quad$ Turbulent Prandtl number;

$Q \quad$ Heat transfer rate, $\mathrm{W}$;

A Surface area of a tube bundle, $\mathrm{m}^{2}$;

$c_{p} \quad$ Specific heat capacity, $\mathrm{J} /(\mathrm{kg} \cdot \mathrm{K})$

$h \quad$ Heat transfer coefficient, $\mathrm{W} /\left(\mathrm{m}^{2} \cdot \mathrm{K}\right)$;

$\mathrm{Nu}$ Nusselt Number;

$\Delta p \quad$ Pressure drop, $\mathrm{Pa}$;

$f \quad$ Friction factor;

$n$ Tubes number;

$N \quad$ Number of main resistance;

$\eta \quad$ Thermal hydraulic performance factor.

\subsection{Greek symbols}

$\rho \quad$ Density, $\mathrm{kg} / \mathrm{m}^{3}$;

$\mu \quad$ Dynamic viscosity, $\mathrm{Pa} \cdot \mathrm{s}$;

$\mu_{T} \quad$ Turbulent eddy viscosity, $\mathrm{Pa} \cdot \mathrm{s}$;

$\eta \quad$ Thermal conductivity, $\mathrm{W} /(\mathrm{m} \cdot \mathrm{K})$

$\varepsilon \quad$ Dissipation rate, $\mathrm{m}^{2} / \mathrm{s}^{3}$.

\subsection{Subscripts}

$\begin{array}{ll}i, j & \text { indexes of vectors; } \\ \text { in } & \text { "inside"; } \\ \text { out } & \text { "outside"; } \\ w & \text { "wall". }\end{array}$




\section{References}

1. Li, X., Wu, X., He, S. (2014). Numerical investigation of the turbulent cross flow and heat transfer in a wall bounded tube bundle. Int. J. Therm. Sci., Vol. 75, pp. 127-139. doi:10.1016/j.ijthermalsci.2013.08.001.

2. Chakrabarty, S. G., Wankhede, U. S. (2012). Flow and heat transfer behaviour across circular cylinder and tube banks with and without splitter plate, Vol. 2.

3. Khan, W. A., Culham, J. R., Yovanovich, M. M. (2006). Convection heat transfer from tube banks in crossflow: Analytical approach. Int. J. Heat Mass Transf., Vol. 49, pp. 4831-4838. doi:10.1016/j.ijheatmasstransfer.2006.05.042.

4. Jeong, J. H., Nam, K. W., Min, J. K., Kim, K. S., Ha, M. Y. (2011). The effects of the evaluation method on the average heat transfer coefficient for a mini-channel tube bundle. Int. J. Heat Mass Transf., Vol. 54, pp. 5481-5490. doi:10.1016/j.ijheatmasstransfer.2011.07.043.

5. Mandhani, V., Chhabra, R., Eswaran, V. (2002). Forced convection heat transfer in tube banks in cross flow. Chem. Eng. Sci., Vol. 57, pp. 379-391. doi:10.1016/S0009-2509(01)00390-6.

6. Li, X., and Wu, X. (2013). Thermal mixing of the cross flow over tube bundles. Int. J. Heat Mass Transf., Vol. 67, pp. 352-361. doi:10.1016/j.ijheatmasstransfer.2013.08.031.

7. Mehrabian, M. (2007). Heat transfer and pressure drop characteristics of cross flow of air over a circular tube in isolation and/or in a tube bank. Arab. J. Sci. Eng., Vol. 32, pp. 365-376.

8. Buyruk, E. (1999). Heat transfer and flow structures around circular cylinders in cross-flow. Tr. J. Eng. Environ. Sci., Vol. 23, pp. 299-315.

9. Bergman, T. L., Lavine, A. S., Incropera, F. P., Dewitt, D. P. (2011). Fundamentals of Heat and Mass Transfer. John Wiley and Sons, New Jersey.

10. Mangrulkar, C. K., Dhoble, A. S., Deshmukh, A. R., Mandavgane, S. A. (2017). Numerical investigation of heat transfer and friction factor characteristics from in-line cam shaped tube bank in crossflow. Appl. Therm. Eng., Vol. 110, pp. 521-538. doi:10.1016/j.applthermaleng.2016.08.174.

11. Tahseen, T. A., Rahman, M. M., Ishak, M. (2014). An experimental study of air flow and heat transfer over. Int. J. Automot. Mech. Eng., Vol. 9, pp. 1487-1500.

12. Mohanty, R. L., Swain, A., Das, M. K. (2018). Thermal performance of mixed tube bundle composed of circular and elliptical tubes. Therm. Sci. Eng. Prog. doi:10.1016/j.tsep.2018.02.009.

13. Barcellos, S. V., Bartz, C. R., Endres, C. L., Moller, L. A. M. (2003). Velocity and pressure fluctuations on inclined tube banks submitted to turbulent flow. J. Brazilian Soc. Mech. Sci. Eng., Vol. 25.

14. Toolthaisong, S., Kasayapanand, N. (2013). Effect of attack angles on air side thermal and pressure drop of the cross flow heat exchangers with staggered tube arrangement. Energy Procedia, Vol. 34, pp. 417-429. doi:10.1016/j.egypro.2013.06.770.

15. Lee, D., Ahn, J., Shin, S. (2013). Uneven longitudinal pitch effect on tube bank heat transfer in cross fl ow. Appl. Therm. Eng., Vol. 51, pp. 937-947. doi:10.1016/j.applthermaleng.2012.10.031.

16. Hofmann, R., Frasz, F., Ponweiser, K. (2007). Heat transfer and pressure drop performance comparison of finned-tube bundles in forced convection. WSEAS Trans. Heat Mass Transf., Vol. 2.

17. Hofmann, R., Frasz, F., Ponweiser, K. (2008). Experimental analysis of enhanced heat transfer and pressure-drop of serrated finned-tube bundles with different fin geometries. 5th WSEAS Int. Conf. Heat Mass Transf., pp. 54-62.

18. Hofmann, R., Frasz, F., Ponweiser, K. (2008). Performance evaluation of solid and serrated finned-tube bundles with different fin geometries in forced convection. 5th Eur. Therm. Conf., Netherlands.

19. Gaddis, E. S. (2010). Pressure drop of tube bundles in cross flow. VDI Heat Atlas, Springer-Verlag, Berlin Heidelberg, pp. 1099-1114.

20. Horvat, A., Leskovar, M., Mavko, B. (2006). Comparison of heat transfer conditions in tube bundle cross-flow for different tube shapes. Int. J. Heat Mass Transf., Vol. 49, pp. 1027-1038. doi:10.1016/j.ijheatmasstransfer.2005.09.030.

21. Nouri-Borujerdi, A., Lavasani, A. M. (2007). Experimental study of forced convection heat transfer from a cam shaped tube in cross flows. Int. J. Heat Mass Transf., Vol. 50, pp. 2605-2611. doi:10.1016/j.ijheatmasstransfer.2006.11.028.

22. Lavasani, A. M., Bayat, H., Maarefdoost, T. (2014). Experimental study of convective heat transfer from in-line cam shaped tube bank in crossflow. Appl. Therm. Eng., Vol. 65, pp. 85-93. doi:10.1016/j.applthermaleng.2013.12.078.

23. Du, X. P., Zeng, M., Dong, Z. Y., Wang, Q. W. (2014). Experimental study of the effect of air inlet angle on the air-side performance for cross-flow finned oval-tube heat exchangers. Exp. Therm. Fluid Sci., Vol. 52, pp. 146-155. doi:10.1016/j.expthermflusci.2013.09.005.

24. Bassi, F., Crivellini, A., Rebay, S., Savini, M. (2005). Discontinuous Galerkin solution of the Reynolds-averaged Navier-Stokes and k- $\omega$ turbulence model equations. Comput. Fluids, Vol. 34, pp. 507-540. doi:10.1016/j.compfluid.2003.08.004.

25. Kuzmin, D., Mierka, O., Turek, S. (2007). On the implementation of the k- $\varepsilon$ turbulence model in incompressible flow solvers based on a finite element discretization. Int. J. Comput. Sci. Math., Vol. 1, pp. 193-206.

26. Park, C. H., Park, S. O. (2005). On the limiters of two-equation turbulence models. Int. J. Comut. Fluid Dyn., Vol. 19, pp. 7986. doi:10.1080/10618560412331286292. 
27. Sveningsson, A., Davidson, L. (2003). Assessment of realizability constraints and boundary conditions in v2-f turbulence models. Turbul. Heat Mass Transf., Vol. 4, pp. 585-592.

28. Young, M. E., Ooi, A. (2004). Turbulence models and boundary conditions for bluff body flow. Proc. 15th Australas. Fluid Mech. Conf., Sydney.

29. Ferziger, J. H., Peric, M. (2002). Computational Methods for Fluids Dynamics. Springer-Verlag, Berlin.

30. Tannehill, J. C., Anderson, D. A., Pletcher, R. H. (1997). Computational Fluid Mechanics and Heat Transfer. Taylor and Francis, Washington.

31. Wilcox, D. C. (2006). Turbulence Modeling for CFD. DCW Industries, California.

32. Gaddis, E. S. (2010). Pressure drop in the outer shell of heat exchangers. VDI Heat Atlas, Springer-Verlag, Berlin Heidelberg, pp. 1115-1128.

33. Holman, J. P. (2010). Heat Transfer. McGraw-Hill, New York.

34. Zukauskas, A., Ulinskas, R. (1985). Efficiency parameters for heat transfer in tube banks. Heat Transf. Eng., Vol. 6, pp. 19-25.

35. Aiba, S., Tsuchida, H., Ota, T. (1982). Heat transfer around tubes in staggered tube banks. Bull. JSME, Vol. 25, pp. $927-933$.

\title{
Числове дослідження впливу кроку труб на теплові та гідравлічні характеристики трубних пучків у поперечному потоці
}

\author{
Пентірін М. О. ${ }^{1}$, Товоджу О. А. ${ }^{2}$, Аджибове С. А. ${ }^{1}$, Зебулун О. Е. ${ }^{1}$ \\ ${ }^{1}$ Університет м. Ібадан, шлях Обудува, м. Ібадан, Нігерія; \\ ${ }^{2}$ Університет Аделеке, Р.М.В. 250, шлях Еде-Осогбо, м. Еде, штат Осун, Нігерія
}

\begin{abstract}
Анотація. У різних теплообмінних апаратах трубні пучки застосовуються для передачі теплової енергії між рідинам. Проте, міжтрубний простів будь-якого трубного пучка є визначальним фактором його теплових і гідравлічних характеристик. У цій роботі чисельно проаналізовано вплив зміни поперечного і поздовжнього кроків у нижній частині трубного пучка на характеристики потоку і теплопередачі. Досліджено сім варіантів розташування труб зі змінним кроком для чисел Рейнольдса у діапазоні від 7381 до 22214 . Аналіз проводився із застосуванням моделі турбулентності $\mathrm{k}-\varepsilon$ із заданими граничними умовами із комп'ютерною реалізацією методом скінченних об'ємів у COMSOL Multiphysics. Отримані результати добре узгоджуються 3 існуючими залежностями. Трубні пучки зі зменшеною відстанню дають кращу теплопередачу. Збільшення ж відстані призводить до зменшення гідравлінчного коефіцієнта тертя.
\end{abstract}

Ключові слова: поперечний потік, змінний крок, трубний пучок, теплопередача, теплотехнічні характеристики. 